\title{
PENERAPAN ANALISIS CLUSTER ENSEMBLE DENGAN METODE ROCK UNTUK MENGELOMPOKKAN PROVINSI DI INDONESIA BERDASARKAN INDIKATOR KESEJAHTERAAN RAKYAT
}

\author{
NADIRA SRI BELINDA, IZZATI RAHMI HG, HAZMIRA YOZZA \\ Program Studi S1 Matematika, \\ Fakultas Matematika dan Ilmu Pengetahuan Alam, Universitas Andalas, \\ Kampus UNAND Limau Manis Padang, Indonesia. \\ email : nadirasri100@gmail.com
}

Diterima 22 Juni 2019 Direvisi 6 Juli 2019 Dipublikasikan 4 Agustus 2019

\begin{abstract}
Abstrak. Kesejahteraan rakyat pada suatu daerah dapat dilihat dari indikator-indikator yang mampu mengukur kesejahteraan rakyat. Kesejahteraan rakyat pada masing-masing daerah berbeda-beda. Oleh karena itu dapat dilakukan pengelompokan daerah di Indonesia untuk melihat kemiripan kondisi kesejahteraan rakyat di suatu daerah dengan daerah lain sehingga dapat membantu pemerintah dalam menyusun dan menentukan prioritas pembangunan. Data indikator kesejahteraan berupa data campuran. Metode pengelompokan yang dapat digunakan untuk menangani data campuran yaitu metode cluster ensemble dengan menggunakan algoritma CEBMDC (Cluster Ensemble Based Mixed Data Clustering) dengan melakukan pengelompokan untuk data numerik dan data kategorik secara terpisah, selanjutnya hasil pengelompokan digabungkan. Objek pengamatan pada penelitian ini adalah 34 provinsi di Indonesia. pengelompokan untuk data numerik menggunakan metode hirarki agglomerative menghasilkan pengelompokan terbaik dengan nilai CP terkecil diperoleh pada metode Ward dengan 2 cluster. pengelompokan data kategorik menggunakan metode ROCK (Robust Clustering Using Links) dengan nilai $\mathrm{CP}^{*}$ terbesar diperoleh pada $\theta=0.30$ yang menghasilkan 4 cluster. Tahap penggabungan (ensemble) menggunakan metode ROCK menghasilkan pengelompokan terbaik pada $\theta=0.30$ dengan nilai $\mathrm{CP}^{*}$ terbesar yang menghasilkan 4 cluster yang terdiri dari 1 provinsi pada cluster 1,19 provinsi pada cluster 2, 10 provinsi pada cluster 3 , dan 4 provinsi pada cluster 4 .
\end{abstract}

Kata Kunci: Cluster Ensemble, CEBMDC, ROCK, CP, CP*

\section{Pendahuluan}

Kesejahteraan pada setiap daerah dapat dilihat berdasarkan indikator-indikator yang mampu mengukur kesejahteraan rakyat dan dapat dijadikan sebagai ukuran tercapai atau tidaknya pembangunan di suatu daerah. Kesejahteraan rakyat pada masing-masing daerah berbeda-beda. Oleh karena itu dapat dilakukan pengelompokan daerah di Indonesia untuk melihat kemiripan kondisi kesejahteraan rakyat 
di suatu daerah dengan daerah lain sehingga dapat membantu pemerintah dalam menyusun dan menentukan prioritas pembangunan.

Data indikator kesejahteraan berupa data campuran. Metode pengelompokan yang dapat digunakan untuk menangani data campuran yaitu metode cluster ensemble dengan menggunakan algoritma CEBMDC (Cluster Ensemble Based Mixed Data Clustering) dengan mengelompokkan data numerik dan kategorik secara terpisah menggunakan metode pengelompokan untuk masing-masing data tersebut, selanjutnya hasil pengelompokan digabungkan dan dipandang sebagai data kategorik yang kemudian dilakukan pengelompokan dengan metode pengelompokan untuk data kategorik [2].

Analisis statistika yang dapat digunakan untuk mengelompokkan objek yaitu analisis cluster. pengelompokan disesuaikan dengan jenis data yang digunakan. Untuk data numerik, pengelompokan dapat menggunakan metode hirarki dan nonhirarki. Untuk data kategorik dapat digunakan metode ROCK, squeezer, dan lainnya. Untuk data campuran (numerik dan kategorik) dapat menggunakan cluster ensemble dengan algoritma CEBMDC.

Penelitian ini akan membahas mengenai pengelompokan provinsi di Indonesia berdasarkan indikator kesejahteraan rakyat. Data indikator kesejahteraan berupa data campuran, sehingga metode yang sesuai untuk digunakan yaitu metode cluster ensemble dengan pengelompokan data numerik menggunakan metode hirarki, sedangkan pengelompokan data kategorik dilakukan dengan metode ROCK. Metode ROCK ini selanjutnya akan digunakan lagi pada tahap penggabungan.

\section{Landasan Teori}

\subsection{Analisis Cluster}

Analisis cluster merupakan salah satu teknik analisis multivariat yang digunakan untuk mengelompokkan $n$ objek ke dalam $m$ cluster dengan $m<n$ berdasarkan karakteristiknya [4]. pengelompokan dilakukan berdasarkan kemiripan atau ketakmiripan antar objek pengamatan sehingga objek yang berada dalam cluster yang sama akan lebih mirip dibandingkan dengan objek antar cluster.

(1) Ukuran kemiripan.

Ukuran kemiripan digunakan untuk mencari pasangan objek yang mirip dalam data. Kemiripan pasangan objek $x$ dan $y$ dinyatakan dengan $\operatorname{sim}(x, y)$. Semakin besar nilai $\operatorname{sim}(x, y)$ menunjukkan semakin mirip pasangan objek $x$ dan $y$. Untuk setiap pasangan objek $x$ dan $y$ berlaku kondisi berikut [6]:

(a) $0 \leq \operatorname{sim}(x, y) \leq 1$

(b) $\operatorname{sim}(x, x)=1$.

(c) $\operatorname{sim}(x, y)=\operatorname{sim}(y, x)$.

(2) Ukuran ketakmiripan.

Ukuran ketakmiripan biasanya digunakan pada data numerik. Ukuran ketakmiripan antara pasangan objek $x$ dan $y$ dinyatakan de-ngan $d(x, y)$. Untuk setiap pasangan objek $x$ dan $y$ berlaku kondisi berikut [6]:

(a) $d(x, y) \geq 0$. 
(b) $d(x, x)=0$.

(c) $d(x, y)=d(y, x)$.

Ukuran jarak merupakan salah satu ukuran ketakmiripan. Ukuran ketakmiripan disebut ukuran jarak jika memenuhi satu kondisi lagi yaitu $d(x, z) \leq$ $d(x, y)+d(y, z)$. Semakin besar nilai ukuran ketakmiripan antara dua objek berarti semakin besar perbedaan antara kedua objek tersebut, sehingga makin cenderung untuk tidak berada dalam cluster yang sama.

\subsection{Metode Pengelompokan}

Pengelompokan dalam analisis cluster dibedakan menurut jenis data yang digunakan yaitu numerik dan kategorik. Berikut akan dijelaskan pengelompokan untuk kedua jenis data tersebut.

(1) Pengelompokan data numerik.

Pengelompokan data numerik dilakukan berdasarkan ukuran ketakmiripan. Ukuran ketakmiripan yang biasa digunakan adalah jarak Euclidean. Misalkan terdapat dua objek dengan $\mathbf{x}=\left(x_{1}, x_{2}, \cdots, x_{n}\right)$ dan $\mathbf{y}=\left(y_{1}, y_{2}, \cdots, y_{n}\right)$, maka jarak Euclidean antara dua objek tersebut adalah [6]:

$$
d(x, y)=\sqrt{\sum_{i=1}^{n}\left(x_{i}-y_{i}\right)^{2}}=\sqrt{(\boldsymbol{x}-\boldsymbol{y})^{T}(\boldsymbol{x}-\boldsymbol{y})} .
$$

Metode yang dapat digunakan untuk pengelompokan data numerik adalah metode hirarki dan non hirarki. Metode hirarki biasanya digunakan bila banyaknya cluster yang akan dibentuk tidak diketahui, sedangkan metode non hirarki biasanya digunakan bila banyaknya cluster yang akan dibentuk ditentukan terlebih dahulu oleh peneliti [5].

Terdapat dua teknik pengelompokan metode hirarki yaitu teknik penggabungan (agglomerative) dan teknik pembagian (divisive). Dalam metode agglomerative setiap kali dilakukan penggabungan cluster, perbaikan jarak antar cluster juga dilakukan. Misalkan $d_{u, w}$ adalah jarak antara cluster $u$ dan $w$, $d_{v, w}$ adalah jarak antara cluster $v$ dan $w, d_{u, v}$ adalah jarak antara cluster $u$ dan $v, n_{u}$ dan $n_{v}$ masing-masing adalah jumlah objek dalam cluster $u$ dan $v$, dinotasikan $d_{(u v) w}$ sebagai jarak baru antara cluster $w$ dengan cluster uv yang merupakan gabungan antara cluster $u$ dan $v$. Jarak antara cluster $u v$ dengan $w$ dapat ditentukan dengan metode perbaikan jarak berikut [4]:

(a) Single Linkage (Pautan Tunggal).

Jarak dua cluster (uv) dengan w menggunakan single linkage ditentukan dengan:

$$
d_{(u v, w)}=\min \left\{d_{(u w)}, d_{(v w)}\right\} .
$$

(b) Complete Linkage (Pautan Lengkap).

Jarak dua cluster (uv) dengan w menggunakan complete linkage ditentukan dengan:

$$
d_{(u v, w)}=\max \left\{d_{(u w)}, d_{(v w)} \cdot\right\}
$$


(c) Average Linkage (Pautan Rataan).

Jarak dua cluster (uv) dengan w menggunakan average linkage ditentukan dengan:

$$
d_{(u v, w)}=\frac{n_{u} d_{u w}+n_{v} d_{v w}}{n_{u}+n_{v}}
$$

(d) Ward.

Jarak dua cluster (uv) dengan w menggunakan metode ward ditentukan dengan:

$$
d_{(u v, w)}=\frac{\left(n_{u}+n_{w}\right) d_{u w}+\left(n_{v}+n_{w}\right) d_{v w}-n_{w} d_{u v}}{n_{u}+n_{v}+n_{w}}
$$

(e) Centroid.

Jarak dua cluster (uv) dengan w menggunakan metode centroid ditentukan dengan:

$$
d_{(u v, w)}=\frac{n_{u} d_{u w}+n_{v} d_{v w}}{n_{u}+n_{v}}-\frac{n_{u} n_{v} d_{u v}}{\left(n_{u}+n_{v}\right)^{2}}
$$

(2) Pengelompokan Data Kategorik.

Pengelompokan data kategorik dilakukan dengan menggunakan ukuran kemiripan. Salah satu metode yang dapat digunakan dalam pengelompokan data kategorik yaitu metode ROCK (Robust Clustering Using Links). Metode ini menggunakan suatu ukuran kemiripan yang disebut link dalam membentuk cluster. Langkah-langkah pengelompokan data kategorik dengan metode ROCK yaitu [1] :

(a) Menghitung kemiripan (similarity).

Ukuran kemiripan antara pasangan objek ke- $i\left(p_{i}\right)$ dengan objek ke- $j\left(p_{j}\right)$ dihitung dengan rumus berikut.

$$
\operatorname{sim}\left(p_{i}, p_{j}\right)=\frac{\left|p_{i} \cap p_{j}\right|}{\left|p_{i} \cup p_{j}\right|},
$$

dimana :

$\left|p_{i} \cap p_{j}\right|=$ banyak kategori yang sama antara objek ke- $i$ dan objek ke- $j$, $\left|p_{i} \cup p_{j}\right|=$ banyak seluruh kategori pada objek ke- $i$ dan objek ke- $j$.

(b) Menentukan tetangga (neighbors).

Objek $p_{i}$ dan $p_{j}$ didefinisikan sebagai tetangga jika $\operatorname{sim}\left(p_{i}, p_{j}\right) \geq \theta$. Threshold $(\theta)$ merupakan parameter yang ditentukan oleh peneliti yang dapat digunakan untuk mengontrol seberapa dekat hubungan antar objek. Nilai $\theta$ yang dapat digunakan adalah $0<\theta<1$.

(c) Menghitung link antar objek pengamatan.

$\operatorname{Link}\left(p_{i}, p_{j}\right)$ didefinisikan sebagai banyaknya tetangga antara $p_{i}$ dan $p_{j}$. Besarnya link dipengaruhi oleh $\theta$ yang ditentukan. Cara menghitung link untuk semua kemungkinan pasangan dari $n$ objek dapat menggunakan matriks A. Matriks A merupakan matriks berukuran $n \times \mathrm{x} n$ yang bernilai 1 jika $p_{i}$ dan $p_{j}$ dinyatakan mirip (tetangga) dan bernilai 0 jika $p_{i}$ dan $p_{j}$ tidak mirip (bukan tetangga). Jumlah link antar pasangan $p_{i}$ dan $p_{j}$ diperoleh 
dari hasil kali antara matriks A dengan matriks A itu sendiri. Jika link antara $p_{i}$ dan $p_{j}$ semakin besar, maka semakin besar kemungkinan $p_{i}$ dan $p_{j}$ berada dalam suatu cluster yang sama.

(d) Menghitung goodness measure masing-masing pasangan objek.

Ukuran kebaikan (goodness measure) untuk menggabungkan dua cluster $C_{i}$ dan $C_{j}$ didefinisikan sebagai berikut:

$$
g\left(C_{i}, C_{j}\right)=\frac{\operatorname{link}\left(C_{i}, C_{j}\right)}{\left(n_{i}+n_{j}\right)^{(1+2 f(\theta))}-n_{i}^{(1+2 f(\theta))}-n_{j}^{(1+2 f(\theta))}},
$$

dengan $\operatorname{link}\left(C_{i}, C_{j}\right)=\sum_{p_{i} \epsilon C_{i}, p_{j} \epsilon C_{j}} \operatorname{link}\left(p_{i}, p_{j}\right)$ yang menyatakan jumlah link dari semua kemungkinan pasangan objek yang ada dalam $C_{i} \operatorname{dan} C_{j}$, serta $n_{i}$ dan $n_{j}$ masing-masing adalah jumlah anggota dalam cluster ke$C_{i}$ dan ke- $C_{j}$, sedangkan $f(\theta)=\frac{1-\theta}{1+\theta}$. Penggabungan objek-objek untuk berada dalam cluster yang sama dilakukan dengan melihat nilai goodness measure tertinggi.

\subsection{Cluster Ensemble}

Cluster ensemble merupakan metode pengelompokan data dengan menggabungkan hasil pengelompokan dari beberapa metode berbeda sehingga diperoleh solusi gabungan sebagai solusi akhir. Hasil pengelompokan dari berbagai metode berupa data kategorik, oleh karena itu kasus cluster ensemble dapat dipandang sebagai kasus pengelompokan data kategorik. Cluster ensemble dapat digunakan dalam menangani data campuran yaitu dengan menggunakan algoritma CEBMDC ( Cluster Ensemble Based Mixed Data Clustering). Langkah-langkah algoritma CEBMDC sebagai berikut [2]:

(1) Memisahkan data campuran menjadi dua bagian data yaitu data kategorik murni dan data numerik murni.

(2) Melakukan pengelompokan dengan algoritma pengelompokan untuk masingmasing jenis data tersebut.

(3) Menggabungkan hasil pengelompokan (output) dari data numerik dan data kategorik. Penggabungan ini disebut proses ensemble.

(4) Melakukan pengelompokan ensemble menggunakan algoritma pengelompokan data kategorik untuk mendapatkan cluster akhir.

\subsection{Evaluasi Hasil Pengelompokan}

Salah satu pengukuran validitas yang dapat digunakan yaitu Compactness (CP). $\mathrm{CP}$ merupakan salah satu kategori pengukuran yang paling umum digunakan. $\mathrm{CP}$ mengukur jarak rata-rata antara setiap pasang titik data yang termasuk dalam cluster yang sama. Berikut rumus yang digunakan untuk menghitung CP untuk data numerik [3]:

$$
C P=\frac{1}{N} \sum_{k=1}^{K} n_{k}\left(\frac{\sum_{x_{i}, x_{j} \epsilon C_{k}} d\left(x_{i}, x_{j}\right)}{n_{k}\left(n_{k}-1\right) / 2}\right),
$$


dengan $K$ adalah banyaknya cluster yang terbentuk, $n_{k}$ adalah jumlah objek pengamatan yang termasuk ke dalam cluster ke- $K, d\left(x_{i}, x_{j}\right)$ adalah jarak antara objek ke- $i$ dan objek ke- $j$, dan $N$ adalah jumlah seluruh objek. Semakin kecil nilai CP, maka cluster yang dihasilkan semakin baik.

Pengukuran validitas untuk data kategorik juga dapat menggunakan compactness dengan mengukur kemiripan rata-rata antara setiap pasang titik data yang termasuk dalam cluster yang sama. Rumus yang digunakan sebagai berikut :

$$
C P *=\frac{1}{N} \sum_{k=1}^{K} n_{k}\left(\frac{\sum_{x_{i}, x_{j} \epsilon C_{k}} \operatorname{sim}\left(x_{i}, x_{j}\right)}{n_{k}\left(n_{k}-1\right) / 2}\right),
$$

dengan $\operatorname{sim}(x i, x j)$ adalah kemiripan antara objek ke- $i$ dan objek ke- $j$. Semakin besar nilai $\mathrm{CP}^{*}$ maka cluster yang dihasilkan semakin baik.

\section{Metode Penelitian}

Data yang digunakan adalah data indikator kesejahteraan rakyat tahun 2017, data tersebut merupakan data publikasi Badan Pusat Statistik (BPS). Objek pengamatan pada penelitian ini adalah 34 provinsi di Indonesia. Dalam penelitian ini digunakan 8 peubah yang terdiri dari 6 peubah numerik dan 2 peubah kategorik yang berupa indikator kesejahteraan dalam bidang ekonomi, pendidikan dan kesehatan. Peubah yang digunakan sebagai indikator ekonomi yaitu persentase penduduk miskin dan tingkat pengangguran terbuka yang berupa data numerik serta kepadatan penduduk dan indeks gizi yang berupa data kategorik. Peubah yang digunakan sebagai indikator pendidikan yaitu angka melek huruf dan angka partisipasi sekolah yang berupa data numerik, dan peubah yang digunakan sebagai indikator kesehatan yaitu angka harapan hidup dan angka morbiditas yang berupa data numerik.

Dalam melakukan pengolahan data digunakan bantuan software $R$ dan software mintab 17. Adapun langkah-langkah penelitian sebagai berikut:

(1) Membagi data menjadi dua bagian, yaitu data numerik murni dan kategorik murni.

(2) Melakukan pengelompokan untuk data numerik menggunakan metode hirarki agglomerative.

(3) Melakukan pengelompokan data kategorik menggunakan metode ROCK.

(4) Pengelompokan terbaik untuk data numerik dilihat dari nilai CP terkecil, dan untuk data kategorik dari $\mathrm{CP}^{*}$ terbesar.

(5) Menggabungkan hasil dari pengelompokan terbaik(tahapan ensemble).

(6) Melakukan pengelompokan kembali dengan metode ROCK.

\section{Pembahasan}

\subsection{Hasil Pengelompokan Data Numerik}

Pengelompokan data numerik dilakukan dengan menggunakan metode hirarki $a g$ glomerative. Tahap pertama yang dilakukan yaitu menyatakan setiap objek pengamatan sebagai suatu cluster dengan anggota tunggal. Selanjutnya membentuk 
matriks jarak antar objek pengamatan dari data numerik yang telah dilakukan standardisasi. Berdasarkan nilai standardisasi data numerik, dihitung jarak Euclidean antar provinsi di Indonesia dengan menggunakan Persamaan 2.1. Jarak Euclidean yang diperoleh dari 34 provinsi dinyatakan dalam matriks $\mathbf{D}$ yang berukuran $34 \mathrm{x}$ 34 .

\begin{tabular}{|c|c|c|c|c|c|c|c|c|c|}
\hline & 1 & 2 & 3 & 4 & $\cdots$ & 31 & 32 & 33 & 34 \\
\hline 1 & {$[0.00$} & 1.89 & 1.90 & 2.05 & & 2.08 & 2.69 & 2.28 & 5.09 \\
\hline $\begin{array}{l}2 \\
3\end{array}$ & $\begin{array}{l}1.89 \\
1.90\end{array}$ & $\begin{array}{l}0.00 \\
1.81\end{array}$ & $\begin{array}{l}1.81 \\
0.00\end{array}$ & $\begin{array}{l}1.30 \\
1.53\end{array}$ & $\cdots$ & $\begin{array}{l}2.09 \\
3.11\end{array}$ & $\begin{array}{l}1.04 \\
1.94\end{array}$ & $\begin{array}{l}2.80 \\
3.55\end{array}$ & $\begin{array}{l}4.67 \\
5.89\end{array}$ \\
\hline & 2.05 & 1.30 & 1.53 & 0.00 & $\because$ & 3.17 & 1.56 & 3.72 & 5.31 \\
\hline 31 & $\begin{array}{ll}1 & 2.08\end{array}$ & 2.09 & 3.11 & 3.17 & & 0.00 & 2.78 & 0.93 & 4.08 \\
\hline $\begin{array}{l}32 \\
33\end{array}$ & \begin{tabular}{l|l}
2.69 \\
3 & 2.28
\end{tabular} & $\begin{array}{l}1.04 \\
2.80\end{array}$ & $\begin{array}{l}1.94 \\
3.55\end{array}$ & $\begin{array}{l}1.56 \\
3.72\end{array}$ & & $\begin{array}{l}2.78 \\
0.93\end{array}$ & $\begin{array}{l}0.00 \\
3.44\end{array}$ & $\begin{array}{l}3.44 \\
0.00\end{array}$ & \\
\hline 34 & ${ }_{4} L 5.09$ & 4.67 & 5.89 & 5.31 & & 4.08 & 4.72 & 4.01 & 0.0 \\
\hline
\end{tabular}

Selanjutnya setelah diperoleh jarak antar provinsi dilakukan penggabungan cluster dengan jarak terdekat dengan memperbarui matriks jarak menggunakan metode hirarki agglomerative yaitu single linkage, complete linkage, average linkage, ward, dan centroid. Tahap berikutnya yaitu menghitung nilai compactness (CP) dari masing-masing metode untuk menentukan hasil pengelompokan terbaik. Pemilihan pengelompokan terbaik dilakukan dengan melihat nilai CP terkecil. Adapun nilai CP hasil pengelompokan dari masing-masing metode dapat dilihat pada Tabel 1 .

Tabel 1. Nilai CP Metode Hirarki Agglomerative

\begin{tabular}{|c|l|c|}
\hline Jumlah Cluster & Metode & CP \\
\hline 3 & Single linkage & 2.7488 \\
\hline 2 & Complete linkage & 2.7777 \\
\hline 3 & Average linkage & 2.7488 \\
\hline 2 & Ward & $\mathbf{2 . 7 4 8 6}$ \\
\hline 3 & Centroid & 2.7488 \\
\hline
\end{tabular}

Berdasarkan Tabel 1, dapat diamati bahwa metode ward memiliki nilai CP terkecil, sehingga metode ini dipilih sebagai metode terbaik untuk pengelompokan data numerik yang menghasilkan 2 cluster. Pada Tabel 2 diberikan anggota cluster untuk metode ward.

\subsection{Hasil Pengelompokan Data Kategorik}

Pengelompokan data kategorik dilakukan dengan menggunakan metode ROCK. Tahap pertama yang dilakukan yaitu menyatakan (inisialisasi) setiap objek pengamatan sebagai suatu cluster dengan anggota tunggal. Selanjutnya membentuk matriks kemiripan antar objek pengamatan dengan menggunakan rumus pada Persamaan (2.7). Kemiripan dari 34 objek pengamatan tersebut dinyatakan dalam matriks similarity (sim) yang berukuran $34 \times 34$. 
Tabel 2. Anggota Cluster Metode Ward

\begin{tabular}{|c|l|}
\hline Cluster & Anggota Cluster \\
\hline 1 & Aceh, Sumatera Utara, Sumatera Barat, Riau, Jambi, \\
& Sumatera Selatan, Bengkulu, Lampung, Bangka Belitung, \\
& Kepulauan Riau, DKI Jakarta, Jawa Barat, Jawa Tengah, \\
& D.I Yogyakarta, Jawa Timur, Banten, Bali, Kalimantan Barat, \\
& Kalimantan Tengah, Kalimantan Selatan, Kalimantan Timur, \\
& Kalimantan Utara, Sulawesi Utara, Sulawesi Selatan, \\
& Sulawesi Tenggara, dan Maluku Utara \\
\hline 2 & Nusa Tenggara Barat, Nusa Tenggara Timur, Sulawesi Tengah, \\
& Gorontalo, Sulawesi Barat, Maluku, Papua Barat dan Papua \\
\hline
\end{tabular}

\begin{tabular}{|c|c|c|c|c|c|c|c|c|c|}
\hline & 1 & 2 & 3 & 4 & $\ldots$ & 31 & 32 & 33 & 34 \\
\hline 1 & {$[1.00$} & 1.00 & 1.00 & 1.00 & & 0.33 & 0.33 & 0.33 & 0.33 \\
\hline $\begin{array}{l}2 \\
3\end{array}$ & $\begin{array}{l}1.00 \\
1.00\end{array}$ & $\begin{array}{l}1.00 \\
1.00\end{array}$ & $\begin{array}{l}1.00 \\
1.00\end{array}$ & $\begin{array}{l}1.00 \\
1.00\end{array}$ & & $\begin{array}{l}0.33 \\
0.33\end{array}$ & $\begin{array}{l}0.33 \\
0.33\end{array}$ & $\begin{array}{l}0.33 \\
0.33\end{array}$ & $\begin{array}{l}0.33 \\
0.33\end{array}$ \\
\hline$n=\stackrel{4}{!}$ & 1.00 & 1.00 & 1.00 & 1.00 & $\because$ & 0.33 & 0.33 & 0.33 & 0.33 \\
\hline 31 & 10.33 & 0.33 & 0.33 & 0.33 & & 1.00 & 1.00 & 1.00 & 1.00 \\
\hline $\begin{array}{l}32 \\
33\end{array}$ & \begin{tabular}{l|l}
0.33 \\
\\
0.33
\end{tabular} & $\begin{array}{l}0.33 \\
0.33\end{array}$ & $\begin{array}{l}0.33 \\
0.33\end{array}$ & $\begin{array}{l}0.33 \\
0.33\end{array}$ & $\ldots$ & $\begin{array}{l}1.00 \\
1.00\end{array}$ & $\begin{array}{l}1.00 \\
1.00\end{array}$ & $\begin{array}{l}1.00 \\
1.00\end{array}$ & $\begin{array}{l}1.00 \\
1.00\end{array}$ \\
\hline 34 & ${ }_{4} L 0.33$ & 0.33 & 0.33 & 0.33 & & 1.00 & 1.00 & 1.00 & 0.00 \\
\hline
\end{tabular}

Tahap selanjutnya ditentukan nilai $\theta$ sebagai batas penentuan tetangga. Informasi mengenai hubungan tetangga antar objek pengamatan dinyatakan dengan matriks A. Matriks A merupakan matriks berukuran 34 x 34 yang bernilai 1 jika objek tersebut bertetangga dan bernilai 0 jika objek tersebut tidak bertetangga. Suatu objek dikatakan bertetangga dengan objek lain jika nilai $\operatorname{sim}>\theta$. Selanjutnya, dilakukan perhitungan jumlah link dan goodness measure. Perhitungan jumlah link diperoleh dengan melakukan perkalian matriks $\mathbf{A}$ dengan matriks $\mathbf{A}$ itu sendiri. Dalam penelitian ini digunakan beberapa nilai threshold $(\theta)$ yaitu $\theta=0.05, \theta=$ $0.10, \theta=0.15, \theta=0.20, \theta=0.25$, dan $\theta=0.30$. Nilai tersebut ditentukan oleh peneliti yang disesuaikan dengan kemiripan objek pengamatan.

Hasil pengelompokan terbaik ditentukan dari nilai compactness $\left(\mathrm{CP}^{*}\right)$ terbesar dari masing-masing dengan menggunakan Persamaan 2.10. Semakin besar nilai $\mathrm{CP}^{*}$ menunjukkan objek-objek dalam cluster yang sama semakin mirip. Adapun nilai $\mathrm{CP}^{*}$ dari masing-masing nilai $\theta$ disajikan pada Tabel 3.

Tabel 3. Nilai CP* Hasil pengelompokan Data Kategorik

\begin{tabular}{|c|c|}
\hline Nilai $\theta$ & CP $^{*}$ \\
\hline 0.05 & 0.4672 \\
\hline 0.10 & 0.4648 \\
\hline 0.15 & 0.4516 \\
\hline 0.20 & 0.4406 \\
\hline 0.25 & 0.4708 \\
\hline 0.30 & $\mathbf{0 . 4 9 7 1}$ \\
\hline
\end{tabular}


Hasil cluster terbaik data kategorik dengan metode ROCK diperoleh pada $\theta$ $=0.30$ dengan menghasilkan 4 cluster. Berikut merupakan anggota setiap cluster yang ditunjukkan pada Tabel 4 .

Tabel 4. Hasil Cluster Data Kategorik dengan Metode ROCK

\begin{tabular}{|c|l|}
\hline Cluster & Anggota Cluster \\
\hline 1 & Gorontalo \\
\hline 2 & Aceh, Sumatera Utara, Sumatera Barat, Riau, \\
& Kepulauan Riau, DKI Jakarta, Jawa Barat, Jawa Tengah, \\
& D.I Yogyakarta, Jawa Timur, Banten, Bali, Kalimantan Timur \\
& Kalimantan Utara, Sulawesi Utara, Sulawesi Tenggara, \\
& Maluku, Maluku Utara, dan Papua Barat \\
\hline 3 & Jambi, Sumatera Selatan, Bengkulu, Lampung, \\
& Bangka Belitung, Nusa Tenggara Barat, \\
& Nusa Tenggara Timur, Kalimantan Selatan, \\
& Sulawesi Selatan, dan Sulawesi Barat, \\
\hline 4 & Kalimantan Barat, Kalimantan Tengah, Sulawesi Tengah, \\
& dan Papua \\
\hline
\end{tabular}

\subsection{Hasil Pengelompokan Data Campuran}

Pengelompokan data campuran dilakukan dengan analisis cluster ensemble dengan menyatakan solusi hasil pengelompokan data numerik dan hasil pengelompokan data kategorik sebagai data baru bertipe kategorik. Selanjutnya, dilakukan tahap analisis yang sama seperti pengelompokan data kategorik yang telah dilakukan sebelumnya dengan metode ROCK. Nilai CP* hasil pengelompokan disajikan pada Tabel 5.

Tabel 5. Nilai CP* Hasil Cluster Ensemble dengan Metode ROCK

\begin{tabular}{|c|c|}
\hline Nilai $\theta$ & CP $^{*}$ \\
\hline 0.05 & 0.4527 \\
\hline 0.10 & 0.4237 \\
\hline 0.15 & 0.4591 \\
\hline 0.20 & 0.4527 \\
\hline 0.25 & 0.4287 \\
\hline 0.30 & $\mathbf{0 . 6 8 9 7}$ \\
\hline
\end{tabular}

Berdasarkan Tabel 5 dapat diamati bahwa nilai $\mathrm{CP}^{*}$ terbesar diperoleh pada $\theta=0.30$ dengan menghasilkan 4 cluster. Pada Tabel 6 dapat dilihat anggota dari masing-masing cluster.

Karakteristik setiap cluster dapat dilihat dari nilai rata-rata setiap cluster nya. Data rata-rata hasil pengelompokan dapat dilihat pada tabel di Gambar 4.3.

Berdasarkan nilai rata-rata peubah numerik untuk setiap cluster, maka dapat diketahui karakteristik tiap cluster sebagai berikut.

(1) Cluster 2 merupakan provinsi dengan kesejahteraan rakyat yang lebih unggul 
Tabel 6. Hasil Cluster Ensemble dengan Metode ROCK

\begin{tabular}{|c|l|}
\hline Cluster & Anggota Cluster \\
\hline 1 & Gorontalo \\
\hline 2 & Aceh, Sumatera Utara, Sumatera Barat, Riau, \\
& Kepulauan Riau, DKI Jakarta, Jawa Barat, Jawa Tengah, \\
& D.I Yogyakarta, Jawa Timur, Banten, Bali, Kalimantan Timur \\
& Kalimantan Utara, Sulawesi Utara, Sulawesi Tenggara, \\
& Maluku, Maluku Utara, dan Papua Barat \\
\hline 3 & Jambi, Sumatera Selatan, Bengkulu, Lampung, \\
& Bangka Belitung, Nusa Tenggara Barat, \\
& Nusa Tenggara Timur, Kalimantan Selatan, \\
& Sulawesi Selatan, dan Sulawesi Barat, \\
\hline 4 & $\begin{array}{l}\text { Kalimantan Barat, Kalimantan Tengah, Sulawesi Tengah, } \\
\text { dan Papua }\end{array}$ \\
\hline
\end{tabular}

\begin{tabular}{|c|c|c|c|c|c|}
\hline \multirow{2}{*}{ Peubah } & \multicolumn{3}{|c|}{ Rata - rata Cluster } & \multirow{2}{*}{ Indonesia } \\
\cline { 2 - 5 } & 1 & 2 & 3 & 4 & \\
\hline $\begin{array}{c}\text { Persentase penduduk } \\
\text { miskin }\left(X_{1}\right)\end{array}$ & 17.14 & 9.65 & 11.67 & 13.78 & 10.12 \\
\hline $\begin{array}{c}\text { Tingkat pengangguran } \\
\text { terbuka }\left(X_{2}\right)\end{array}$ & 3.65 & 5.73 & 3.75 & 3.57 & 5.33 \\
\hline $\begin{array}{c}\text { Angka melek huruf } \\
\left(X_{3}\right)\end{array}$ & 99.06 & 98.38 & 97.46 & 97.93 & 97.78 \\
\hline $\begin{array}{c}\text { Angka partisipasi } \\
\text { sekolah }\left(X_{4}\right)\end{array}$ & 69.86 & 76.57 & 71.49 & 68.09 & 71.42 \\
\hline $\begin{array}{c}\text { Angka harapan } \\
\text { hidup }\left(X_{5}\right)\end{array}$ & 69.20 & 72.39 & 70.16 & 69.92 & 73.06 \\
\hline $\begin{array}{c}\text { Angka morbiditas } \\
\left(X_{6}\right)\end{array}$ & 20.56 & 13.48 & 13.70 & 13.00 & 14.31 \\
\hline
\end{tabular}

dibandingkan cluster lainnya, yaitu dalam bidang ekonomi, pendidikan, dan kesehatan. Dalam bidang ekonomi, persentase penduduk miskin cluster ini rendah dibandingkan dengan cluster lainnya, walaupun tingkat pengangguran terbuka nya tinggi. Dalam bidang pendidikan, untuk angka melek huruf dan angka partisipasi sekolah cluster ini cukup tinggi. Untuk bidang kesehatan, cluster ini juga baik ditandai dengan angka harapan hidup penduduknya yang lebih tinggi dari cluster lain, dan angka morbiditasnya yang rendah.

(2) Cluster 1 merupakan provinsi yang membutuhkan prioritas dalam bidang kesehatan, yang ditandai dengan angka harapan hidup yang lebih rendah dibandingkan cluster lainnya, dan angka morbiditas yang tinggi dibandingkan cluster lainnya. Dilihat dari bidang ekonomi, cluster ini juga kurang baik, ditandai dengan persentase penduduk miskin yang lebih tinggi dibandingkan cluster lainnya, walaupun tingkat pengangguran terbuka nya rendah. Untuk bidang pendidikan yang dilihat dari angka melek huruf dan angka partisipasi sekolah cluster ini cukup baik.

(3) Cluster 3 dan 4 merupakan provinsi dengan kesejahteraan rakyat yang relatif mirip dalam bidang ekonomi yang dilihat dari persentase penduduk miskin dan tingkat pengangguran terbuka, serta dalam bidang kesehatan yang dilihat dari angka harapan hidup dan angka morbiditas. Kedua cluster ini membutuhkan 
prioritas dalam bidang pendidikan. Untuk cluster 3, angka melek huruf nya lebih rendah dibandingkan cluster lainnya. Untuk cluster 4 angka partisipasi sekolahnya lebih rendah dibandingkan cluster lainnya.

Tabel 7. Karakteristik Peubah Kategorik Cluster Ensemble ROCK

\begin{tabular}{|c|c|c|c|c|c|}
\hline Peubah & Kategori & Cluster 1 & Cluster 2 & Cluster 3 & Cluster 4 \\
\hline Kepadatan & Tidak padat & $0 \%$ & $26 \%$ & $0 \%$ & $100 \%$ \\
penduduk & Kurang padat & $100 \%$ & $37 \%$ & $90 \%$ & $0 \%$ \\
& Cukup padat & $0 \%$ & $0 \%$ & $10 \%$ & $0 \%$ \\
& Sangat padat & $0 \%$ & $37 \%$ & $0 \%$ & $0 \%$ \\
\hline indeks gizi & Rendah & $0 \%$ & $84 \%$ & $90 \%$ & $100 \%$ \\
& Sedang & $100 \%$ & $16 \%$ & $10 \%$ & $0 \%$ \\
\hline
\end{tabular}

Tabel 7 memperlihatkan bahwa cluster 1 merupakan provinsi dengan kepadatan penduduknya tergolong kurang padat, dan indeks gizinya sedang. Untuk cluster 2 didominasi oleh provinsi dengan kepadatan penduduknya kurang padat dan sangat padat, sedangkan indeks gizinya rendah. Cluster 3 didominasi oleh provinsi dengan kepadatan penduduknya kurang padat dan indeks gizinya rendah. Cluster 4 kepadatan penduduknya berkategori tidak padat dan indeks gizinya rendah.

\section{Kesimpulan}

Berdasarkan hasil pengolahan data dapat disimpulkan bahwa:

(1) Hasil pengelompokan cluster ensemble terbaik diperoleh pada $\theta=0.30$ yang menghasilkan 4 cluster. Cluster 1 terdiri dari 1 provinsi yaitu Gorontalo. Cluster 4 terdiri dari 4 provinsi yaitu Kalimantan Barat, Kalimantan Tengah, Sulawesi Tengah, dan Papua. Cluster 3 terdiri dari 10 provinsi yaitu Jambi, Sumatera Selatan, Bengkulu, Lampung, Bangka Belitung, Nusa Tenggara Barat, Nusa Tenggara Timur, Kalimantan Selatan, Sulawesi Selatan, dan Sulawesi Barat. Untuk 19 provinsi lainnya termasuk ke dalam cluster 2.

(2) Cluster 2 merupakan cluster yang lebih unggul kesejahteraan rakyatnya dibandingkan cluster lainnya yaitu dalam bidang ekonomi, pendidikan, dan kesehatan. Kepadatan penduduk cluster ini didominasi oleh provinsi dengan kepadatan penduduk yang kurang padat dan sangat padat, serta indeks gizi yang rendah. Cluster 1, 3, dan 4 relatif mirip kesejahteraan rakyatnya. Cluster 1 membutuhkan prioritas dalam bidang kesehatan, yang ditandai dengan angka harapan hidup yang lebih rendah dibandingkan cluster lainnya, dan angka morbiditas yang tinggi dibandingkan cluster lainnya. Kepadatan penduduk cluster ini tergolong kurang padat dan indeks gizi nya sedang. Cluster 3 dan 4 membutuhkan prioritas dalam bidang pendidikan. Cluster 3 merupakan provinsi dengan angka melek huruf yang lebih rendah dibandingkan cluster lainnya. Kepadatan penduduk cluster ini didominasi oleh provinsi yang tergolong kurang padat dan indeks gizi yang rendah. Untuk cluster 4 angka partisipasi 
sekolahnya lebih rendah dibandingkan cluster lainnya. Kepadatan penduduk cluster ini tergolong tidak padat dan indeks gizi yang rendah.

\section{Daftar Pustaka}

[1] Guha, S., R. Rastogi, dan K. Shim. 1999. ROCK: A Robust Clustering Algorithm for Categorical Attributes. Proceedings of the IEEE Conference on Data Engineering: $512-521$

[2] He, Z., Xu. X dan S. Deng. 2005. A Cluster Ensemble Method For Clustering Categorical Data. Information Fusion. 6(2): 143 - 151

[3] Iam-on N, Garret S. 2010. LinkCluE: A MATLAB Package for Link-Based Cluster Ensemble. Journal of Statistical Software. 36(9): 1 - 3

[4] Johnson, R. A. dan D.W. Winchern. 2007. Applied Multivariate Statistical Analysis (sixth ed). Prentice Hall, New Jersey

[5] Mattjik, A.A. dan I.M. Sumertajaya. 2011.Sidik Peubah Ganda dengan Menggunakan SAS. IPB Press, Bogor

[6] Spath, Helmuth. 1982. Cluster Analysis Algorithms: For Data Reduction and Classification of Objects. University of Oldenburg, Germany 